\title{
Ecological function as a criterion for the evaluation of conservation: the case of the river Dulce (Guadalajara, Spain)
}

\author{
M. A. Bravo-Utrera ${ }^{1}$, J. A. Atauri² \& M. Del Pozo ${ }^{3}$
}

1Equipo de Seguimiento de Procesos Naturales. Estación Biológica de Doñana-CSIC. Palacio de Doñana s/n. 21760-Matalascañas. E-mail: mabravo@ebd.csic.es. 2Depto. De Ecología. Facultad de Ciencias. Universidad de Alcalá de Henares. E mail joseantonio.atauri@uni.uah.es. 3TRAGSATEC, S.A. Avda. Ciudad de Barcelona, 114. 28007 - Madrid. E-mail: mpm@tragsatec.es

\begin{abstract}
An ecological evaluation of the River Dulce was conducted, as part of the management plan of the whole basin of this river. Homogeneous sectors according to ecosystem structure and function were identified. Habitats along the river course were described and water quality evaluated, allowing the division of the river in sectors.Ecosystems usually considered of minor importance using faunal or landscape-aesthetic criteria, are assessed as being of high ecological value because of their function in the control of perturbations.
\end{abstract}

Key words: ecological evaluation, conservation evaluation, river conservation.

\section{RESUMEN}

En el contecto de la planificación del cuenca del río Dulce, se ha realizado una evaluación ecológica, identificando sectores homogéneos de acuerdo con la función y estructura del ecosistema. Una caracterización de los hábitats a lo largo del curso del río y una tipificación de la calidad del agua ha permitido una sectorización del río. Ecosistemas considerados de importancia menor a partir de criterios faunísticos o estético-paisajistas han sido evaluados como de elevado valor ecológico gracias a su función como tamponador de los efectos de perturbaciones.

Palabras clave: evaluación ecológica, evaluación de la conservación, conservación fluvial.

\section{INTRODUCTION}

Since the 1980s, a large number of areas in Europe (IUCN, 1994) and Spain (Azcárate et al., 1996) have been designated as protected zones. More than 800 of these areas now exist in Spain. However, this increase in protection effort has often not been guided by sound knowledge of the structure and functioning of ecosystems. Since the designation of the first National Parks (191030 ), based on landscape aesthetic criteria and inspired by alpine-like models, designation and management of protected areas has been evolving towards other criteria like the abundance of game species (1970s), or the presence of certain conspicuous species (1980s). Only in the last decade have ecologically based criteria started to be used (Montes, 1995). An analysis of the criteria explicitly stated in Spanish laws for the designation of protected areas, reveals that in $26 \%$ of occasions, criteria were sociopolitical, $24 \%$ were administrative, and only the remaining $49 \%$ of analysed occasions were knowledge-based decisions. Moreover, in this $49 \%$ of cases, criteria 
were more often than not, related to aesthetic preference and criteria were generalistic and distorted by political and administrative criteria (Fernández Sañudo et al., 1997).

However, functional aspects of ecosystems are largely unknown. Also, urgency for adopting protection measures, has led to the frequent adoption of representativeness as the selection criterion. This criterion is also considered one of the most effective (Usher, 1986; González Bernáldez, 1988). However, if we admit that the main objectives of the protection of areas are to ensure the conservation of biodiversity through the conservation of ecological integrity and the maintenance of ecological functions and evolutionary processes (Montes, 1995; Davidson et al., 1996; Múgica et al., 1996), then it is clear we still need to consider functional aspects in ecological evaluation (Pineda et al., 1991; Montes, 1995). The management of these areas should be based on knowledge of the key factors controlling the biophysical processes responsible for ecosystem integrity, in order to guarantee its persistence in the long term, and the ability to resist perturbations (Montes et al., in press). The application of these criteria could allow the selection of systems which are crucial to the functioning of the whole ecosystem. Conventional criteria may be underselecting these key systems.

Landscape aesthetic quality has often been the criterion used to evaluate the conservation interest of aquatic ecosystems, especially of rivers (Martínez et al., 1989; Montes \& Martín de agar, 1989). Other criteria used for aquatic ecosystems have been water quality, conservation status of riparian vegetation and its species composition, and the presence of conspicuous or endangered species (e.g. big raptors, ducks) (Amat et al., 1985; Cirujano et al., 1992; Sterling, 1995; Ibero, 1996)

The increasing development of conservation networks in Europe has stressed the need for a clear definition of which should be the criteria for ecological evaluation. This should be used for both the designation of protected areas and for their management as well. In this paper, a case study is presented which discusses the impor- tance of including functional criteria for ecological evaluation in the River Dulce basin. It is shown, functional criteria allow the detection of key systems essential for the functioning of the whole ecosystem, which have not been properly evaluated using other criteria.

\section{STUDY AREA}

The River Dulce rises in Sierra Ministra, in the Iberian Range (Fig. 1), at $1300 \mathrm{~m}$ a.s.1. It is $43 \mathrm{~km}$ long and its catchment basin has a surface area of $263 \mathrm{~km}^{2}$. It is a tributary of the River Henares in the River Tajo basin.

The study area corresponds to the mediumlower section of the River Dulce, between the towns of Jodra del Pinar and Aragosa. In the lower half of the study area, landscape is defined by deep canyons and cliffs produced by erosion of the limestone rock. Landforms of open-valley with smooth slopes are predominant in the upper section. This morphology determines a characteristic distribution of vegetation. The "páramos", or open higher plains are mostly dedicated to agriculture. Open forests of Quercus rotundifolia and Quercus faginea exist on the smooth slopes, while cliffs possess a sparse but interesting vegetation. The riparian vegetation has been replaced

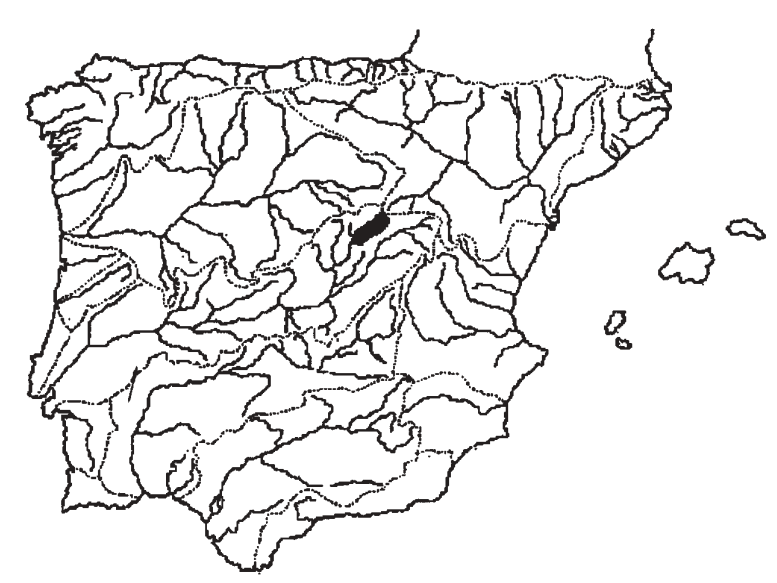

Figure 1. Situation of the River Dulce basin (Spain). Situación de la cuenca del río Dulce. 
in wide stretches of the river by Populus sp. plantations, or has been dedicated to agriculture.

\section{MATERIAL AND METHODS}

The limnological study of the River Dulce was proposed as part of planning efforts for the management of the basin ("Plan de Ordenación de los Recursos Naturales"). The main aim was to characterize existing habitats and diagnose their ecological state.

Information was recorded about channel morphology (slope, flow speed, texture and granulometry of sediments), conservation status of riparian vegetation and apparent water quality.

Four sampling sites were established along the course of the river. Water temperature, conductivity, $\mathrm{pH}$, dissolved oxygen, Biological Oxygen Demand $\left(\mathrm{BOD}_{5}\right)$, Total Suspended Solids (TSS), organic matter, major ions, silica and nutrients were measured. Also, the biological water quality index BMWP' was computed (Alba-Tercedor and Sánchez Ortega, 1988; see
Table 1). Sampling was carried out on September 25 and 26, 1996.

From data, hypotheses about river functioning were formulated. The operational aim was to recognize homogeneous sectors which could be used as a basis for the planning and future management of the area.

\section{RESULTS}

\section{Habitat characterization}

Four sectors can be defined along the river, which are homogeneous in the frequency and distribution of aquatic habitats (Fig. 2).

\section{Sector I.}

The first sector is defined by its smooth slope and the dominance of sedimentary processes. Sediments of fine texture are predominant and the river channel is almost undefined. Where the river channel still has its original configuration, it

Tabla 1. Physico-chemical variables measured in River Dulce (Spain) during September 1996. Variables fisico-químicas medidas en cada una de las estaciones de muestreo.

\begin{tabular}{|c|c|c|c|}
\hline VARIABLE & UNITS & METHOD & REFERENCE \\
\hline FLOW & $\mathrm{m}^{3} \mathrm{~s}^{-1}$ & Electronic winch & \\
\hline TEMPERATURE & ${ }^{\circ} \mathrm{C}$ & Thermistor & \\
\hline CONDUCTIVITY & $\mu \mathrm{S} \mathrm{cm} \mathrm{cm}^{-1}$ & Conductivimeter MTW 90 & \\
\hline $\mathrm{PH}$ & & $\begin{array}{l}\mathrm{pH} \text { Merck } 0.5 \text { indicators } \\
\text { electrode }\end{array}$ & \\
\hline DISSOLVED O² & $\mathrm{mg} \mathrm{L}^{-1}$ & Winkler & APHA, 1989 \\
\hline BIOLOGICAL & $\mathrm{mg} \mathrm{L}^{-1}$ & Winkler. incubation at $20^{\circ} \mathrm{C}$ & APHA, 1989 \\
\hline OXYGEN & & during 5 days & \\
\hline \multicolumn{4}{|l|}{ DEMAND $\left(\mathrm{BOD}_{5}\right)$} \\
\hline $\mathrm{PO}_{4}{ }^{3-}$ & $\operatorname{mgP~L}{ }^{-1}$ & Ascorbic acid colorimeter & APHA, 1989 \\
\hline \multirow[t]{2}{*}{$\mathrm{NH}^{4+}$} & $\mathrm{mgN} \mathrm{L}^{-1}$ & Colorimetry of 2,2'- & Espectroquant ${ }^{\circledR}$ \\
\hline & & $\begin{array}{l}\text { isopropyl-5,5'-methylindophenol blue. } \\
\text { Berthelot reaction }\end{array}$ & 14752, Merck \\
\hline $\mathrm{NO}^{2}$ & $\operatorname{mgN~L}{ }^{-1}$ & Colorimetry & APHA, 1989 \\
\hline $\mathrm{NO}^{3}$ & $\mathrm{mgN} / \mathrm{L}$ & Colorimetry & APHA, 1989 \\
\hline TOTAL SUSPENDED & $\mathrm{g} \mathrm{L}^{-1}$ & Gravimetry & APHA, 1989 \\
\hline \multicolumn{4}{|l|}{ SOLIDS (TSS) } \\
\hline \multicolumn{4}{|l|}{ ALKALINITY } \\
\hline \multirow[t]{2}{*}{$\mathrm{CO}^{32-}+\mathrm{HCO}^{3-}$} & $\mathrm{mg} \mathrm{L}^{-1}$ & & \\
\hline & meq $\mathrm{L}^{-1}$ & Volumetric & APHA, 1989 \\
\hline
\end{tabular}




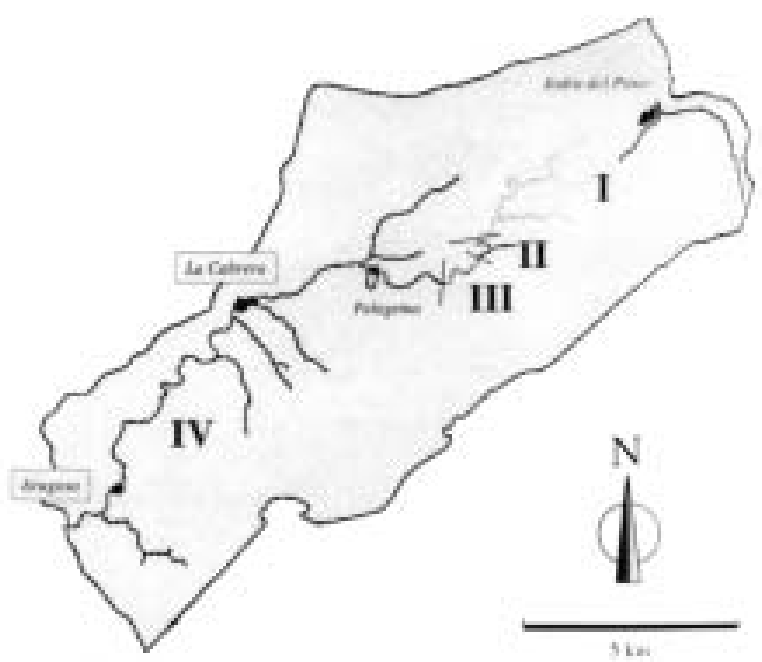

Figure 2. Division in sectors of homogeneous characteristics of the River Dulce in the study area. Sectorización del río Dulce en el área de estudio.

forms a slight valley with smooth banks, suggesting a wide seasonal variation in the wet perimeter occurs, following changes in rainfall levels and river discharge.

Vegetation is organized in a catena, with Phragmites australis occupying the band closest to the water and, with successive bands of Phalaris arundinacea and Elymus hyspidus. The latter species defines the maximum inundation line. Above this line, an open wood of Quercus rotundifolia covers South-facing slopes. Quercus faginea tend to grow on slopes oriented to the North. Groundwater-loving species, such as Salix alba, Fraxinus angustifolia or Populus nigra, appear locally along the river course (Fig. 3). As the river widens, the main channel divides into small streams, with more permanent and slowflowing water. The river thus acquires a clear, lentic nature. Here, wide extensions of Carex sp. formations can be found.

The river channel has been strongly altered in this sector. The channel has been cut to trapezoidal section and has a variable depth of 1 to 3 $\mathrm{m}$. This prevents overflow in ordinary floods, facilitating agricultural use of surrounding lands. The cover of helophytic vegetation has reduced significantly, and now grows only in scattered clumps. Dominant plant species are typically cosmopolitan, adapted to permanent water and to a certain degree of organic pollution (e.g. Phragmites australis, Typha latifolia and Sparganium erectum). Exterior fringes are adapted to periodic flooding and are replaced by macrophytes such as Chara sp., and species such as Veronica anagallis-aquatica and Apium nodiflorum which are favoured by the higher nutrient levels of the water. In these areas, plantations of Populus sp. and Fraxinus sp. along the banks are quite common.

\section{Sectors II and III}

Sectors II and III are considered transition or intermediate sectors. A negative balance is maintained with the aquifer. Water flow becomes progressively less important towards summer, only flowing through the surface during the rainy season. In summer the river is reduced to isolated pools in these sectors.

Bed granulometry is variable, ranging from coarse with rocky outcrops, where erosion is important, to fine in zones similar to sector I. Aquatic vegetation is scarce, dominated by species of temporal waters, such as Chara sp. in pools, and Phragmites australis on banks. Fish diversity is limited by the low proportion of habitats with enough water lasting throughout their life cycle. In these sectors, suitable habitats are found for species of small size and wide ecological spectrum. For instance, Leuciscus pyrenaicus ("cacho"), Gobio gobio ("gobio"), Cobitis maroccana ("colmilleja") and Rutilus arcasii ("bermejuela") may be found, although only

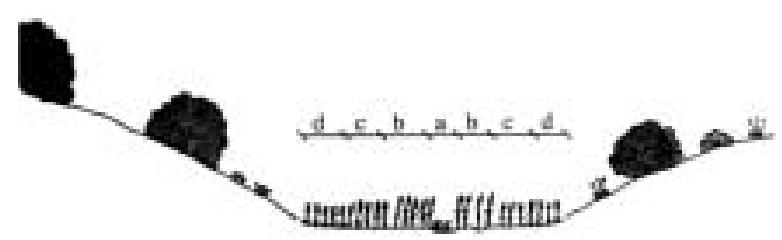

Figure 3. Cross-section of the River Dulce valley (Sector I). Corte transversal del valle del río Dulce, sector I 


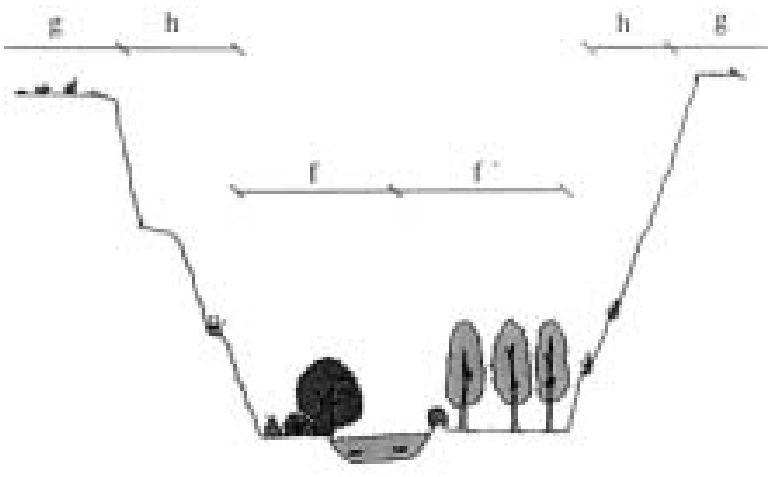

Figure 4. Cross-section of the River Dulce valley (Sector IV). Corte transversal del valle del río Dulce, sector IV.

when water levels are maintained. Small populations can become confined during the summer to isolated pools.

\section{Sector IV}

This is the longest and most complex of all sectors. It is a discharge area, which buffers annual flow variations. This sector of the river helps

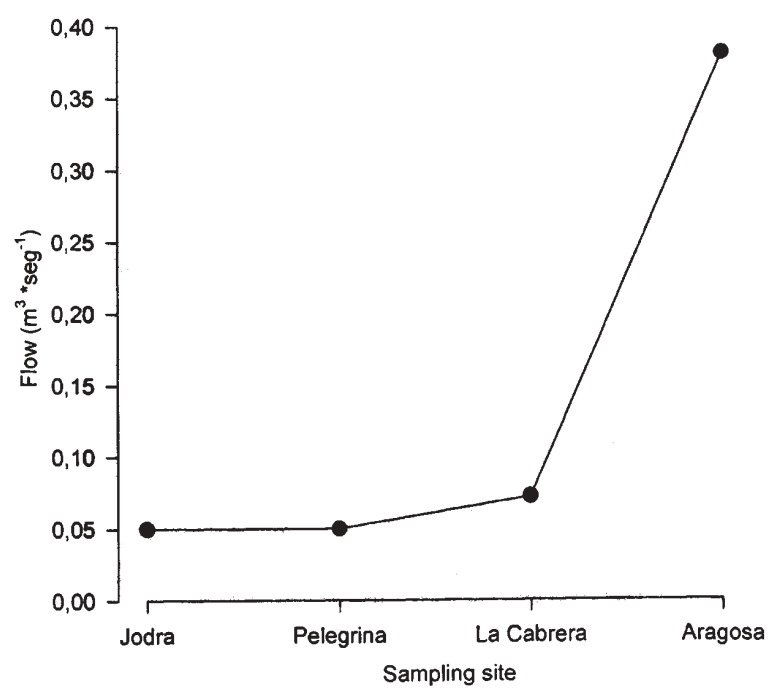

Figure 5. Diagram showing river flows at study sites in the River Dulce (Spain), ordered from left to right according to flow direction. Diagrama de caudal en las estaciones de muestreo, ordenadas de izquierda a derecha en el sentido de la corriente. maintain a flow, despite seasonal variations in discharge. Flow increases downstream. The river channel is well defined, with steep banks. The floodplain has been altered with ridges, to allow use for cultivation (Fig. 4). The river bed is dominated by gravel in lotic facies, and sand and mud in lentic ones.

Disperse specimens of Apium nodiflorum, Veronica anagallis-aquatica and Rorippa nasturtium-aquaticum occur in areas protected from the water flow. In sandy banks and pools cosmopolitan species can be found, such as Phragmites australis, Typha latifolia and Sparganium erectum, with dense cover of Chara sp. and Groendlandia densa covers the bottom of pools and artificial ponds.

There are large fish populations in this sector. Species also found upstream can live here, as well as native, genetically-pure populations of Salmo trutta. Thus, there is potential for sport fishing, too. Barbus bocagei and Chondrostroa polylepis also occur, as occasional migrants (Estudios Biológicos, 1996).

\section{Water quality}

Table 2 summarizes sampling results at four sites along the river.

Sampling was done during the low flow period. Then, the relationship between surface water and groundwater is clear. Figure 5 shows flow variation along the course. Sectors I, II and III include the sampling sites of Jodra del Pinar and Pelegrina, while the rest of the sampling sites are in sector IV (Fig. 2). Flow remains almost constant for most of the course, increasing greatly from La Cabrera. This is attributed to the incorporation of spring waters to the river.

Changes in conductivity along the course (Fig. 6) are inversely related to flow during low water regimes. Values for this variable ranged between 576 and $699 \mathrm{mS} \mathrm{cm}^{-1}$. Thus, it can be described as "oligohaline water". Alkalinity values were fairly stable at $300 \mathrm{mg} \mathrm{l}^{-1}$. pH varied between 7 and 8 (Fig. 6). Thus, the water can be classified as highly-buffered hard water. The concentration of total 
Tabla 2. Values of main physico-chemical and water quality variables measured in the four sampling sites in River Dulce (Aragosa, La Cabrera, Pelegrina and Jodra). Units as in Table 1. Tabla 2. Valores de las principales variables fisico químicas y de calidad del agua, en cada una de las estacioens de muestreo.

\begin{tabular}{|c|c|c|c|c|}
\hline SAMPLING SITE & Aragosa & La Cabrera & Pelegrina & Jodra \\
\hline Flow & 0.381 & 0.072 & 0.050 & 0.050 \\
\hline Water temperature & 13.00 & 12.50 & 13.90 & 11.50 \\
\hline Conductivity & 576.00 & 699.00 & 684.00 & 699.00 \\
\hline Alkalinity & 333.60 & 319.80 & 332.25 & 303.00 \\
\hline $\mathrm{pH}$ & 7.00 & 7.30 & 7.70 & 7.60 \\
\hline DO & 9.878 & 11.172 & 10.208 & 6.904 \\
\hline $\mathrm{BOD}^{5}$ & 3.334 & 2.252 & 2.406 & 2.014 \\
\hline TSS & 0.0037 & 0.0028 & 0.0030 & 0.0133 \\
\hline PRS & 0.0050 & 0.0095 & 0.0175 & 0.0384 \\
\hline $\mathrm{NH}^{4+}$ & 0.2059 & 0.2059 & 0.2704 & 0.3229 \\
\hline $\mathrm{NO}^{2-}$ & 0.0026 & 0.0022 & 0.0032 & 0.0066 \\
\hline $\mathrm{NO}^{3-}$ & 4.0236 & 1.5794 & 1.2642 & 3.2688 \\
\hline BMWP' & 101 & 140 & 137 & 71 \\
\hline Taxonomic richness & 17 & 24 & 24 & 15 \\
\hline
\end{tabular}

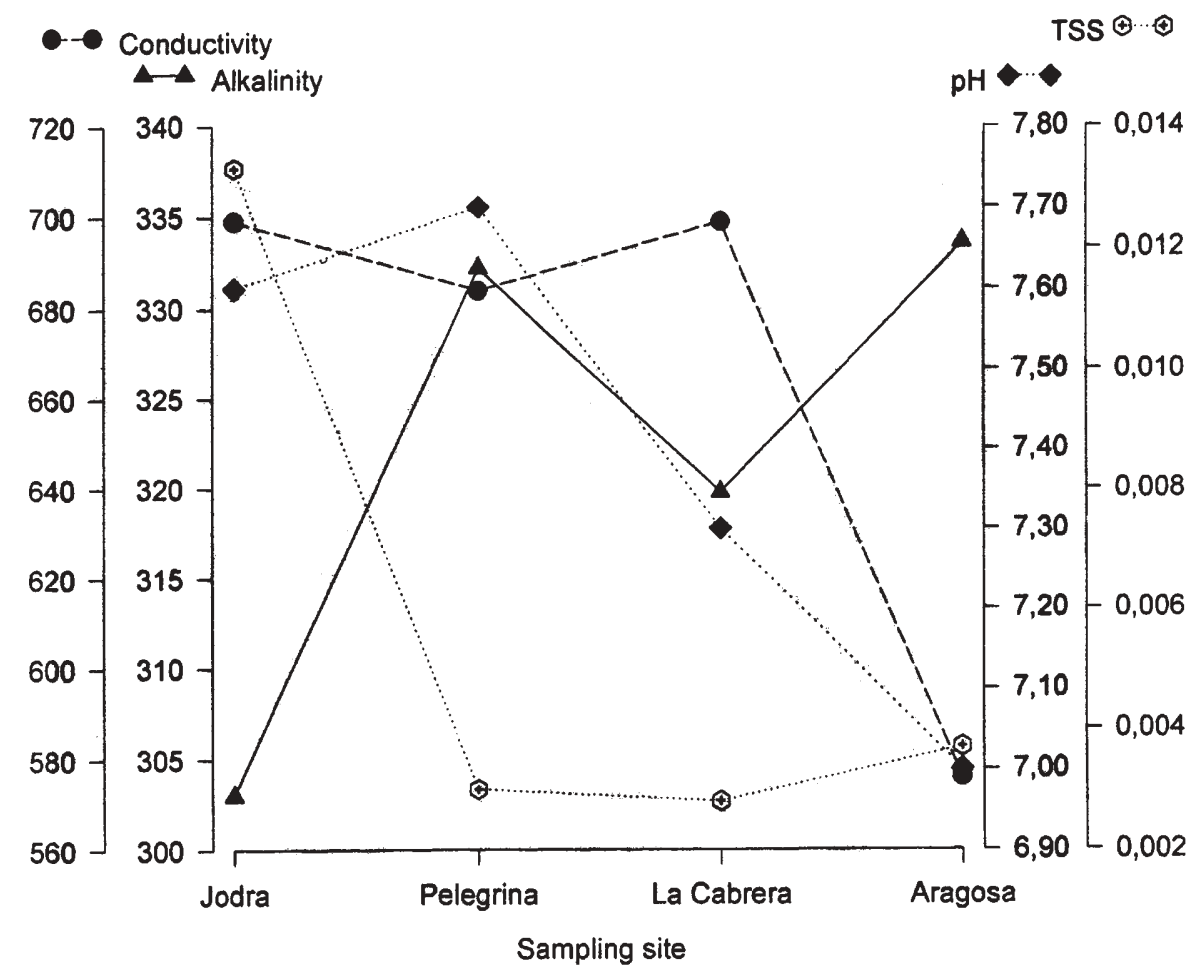

Figure 6. Spatial changes in conductivity, alkalinity, $\mathrm{pH}$ and total suspended solids in the River Dulce (Spain). Evolución espacial de la conductividad, alcalinidad, pH y total de sólidos en suspensión. 


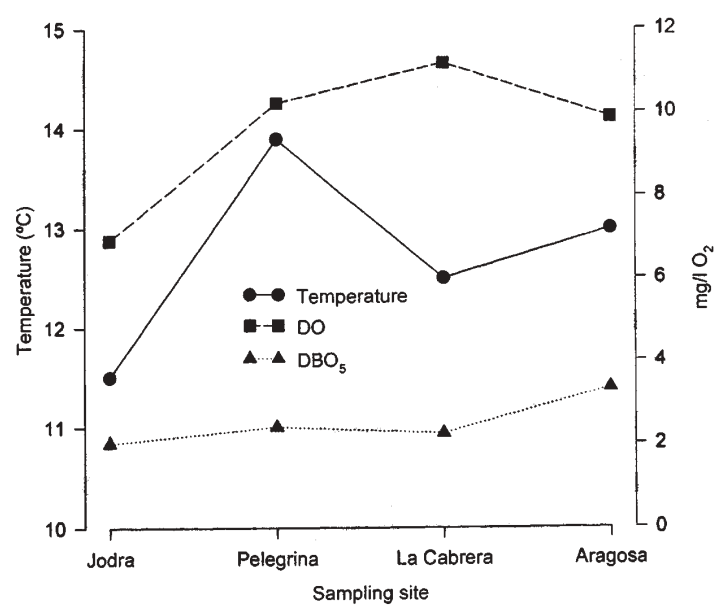

Figure 7. Spatial changes in temperature, dissolved oxygen and DBO5 in the River Dulce (Spain). Evolución espacial de la temperatura, oxigeno disuelto y $\mathrm{DBO5}$. suspended solids was higher at the first sampling site, where the river enters the study area, decreasing immediately after. High concentrations were not recorded, but intense transformation of the basin has occurred, suggesting that high loads could occur during high water regimes. The concentration of dissolved oxygen and its relationship with water temperature (Fig. 7) shows an important recovery in the first section, and then stabilises. The Biological Oxygen Demand $\left(\mathrm{BOD}_{5}\right)$, remained under limits set by law, except at sampling site further downstream, where values in excess of $3 \mathrm{mg} \mathrm{l}^{-}$ ${ }^{1}$ were measured.

Changes in nutrient concentrations $(\mathrm{N} \& \mathrm{P})$ are shown in Figure 8. The Jodra sampling site showed high nutrient levels, indicating intense organic pollution. Values of $\mathrm{NH}_{4}^{+}$and $\mathrm{NO}_{2}^{-}$

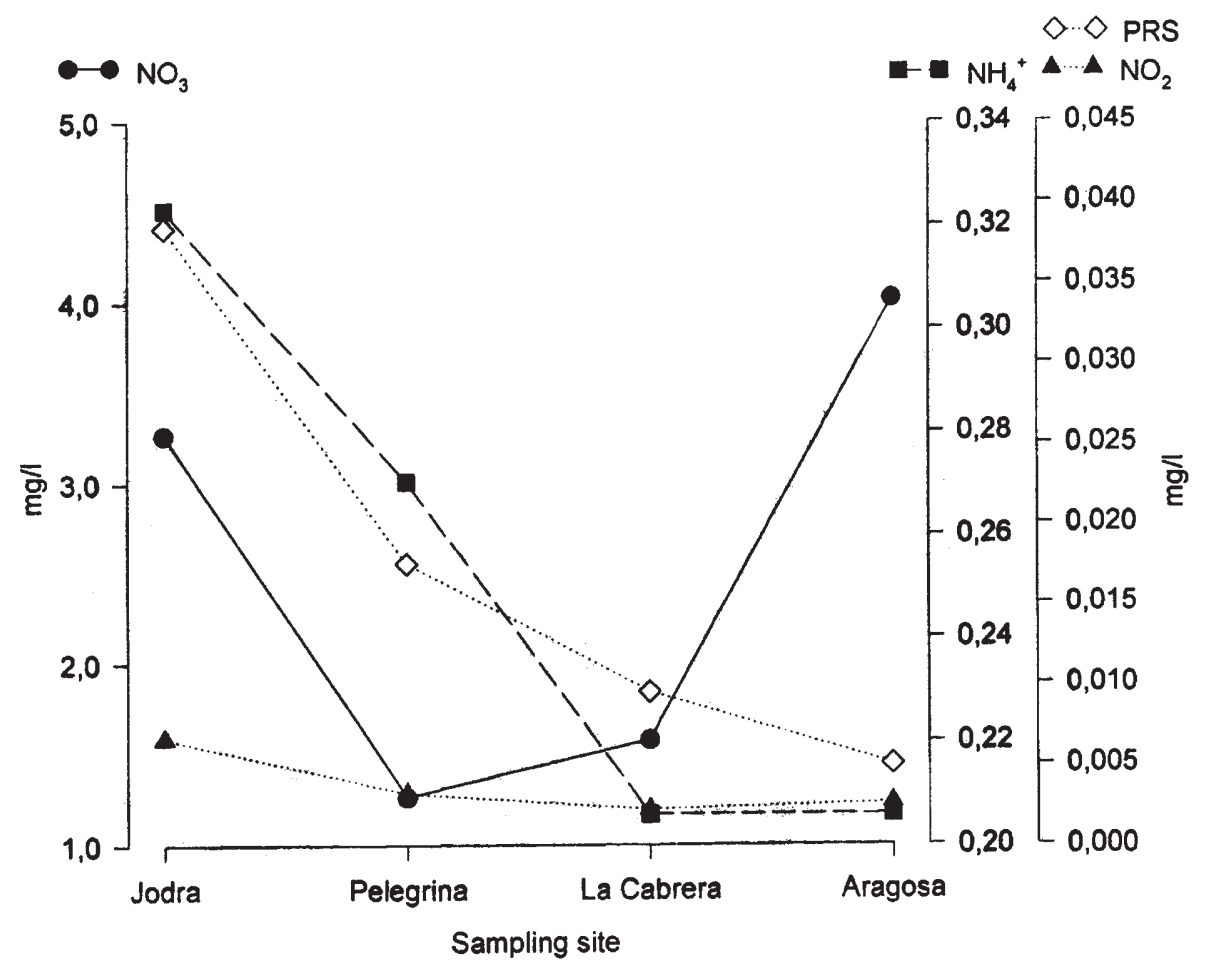

Figure 8. Spatial changes in nutrient concentrations in the River Dulce (Spain). Evolución espacial de la concentración de nutrientes. 
widely surpassed recommended levels for maintaining healthy fish populations.

In next sampling site downstream, nutrient concentrations were somewhat lower, revealing an increase in water quality through this first sector, except for $\mathrm{NO}_{3}^{-}$concentration, which was higher at the sampling site further downstream.

Water quality, estimated by the BMWP' index and by the taxonomic richness in river macrobenthos (Fig. 9), was worst at Jodra and best at La Cabrera. Low water quality was measured in Aragosa. Except for the first sampling site, assigned to Class II, the remaining sites were assigned to Class I, meaning most of the river has water of good quality.

\section{DISCUSSION}

The River Dulce is a typically Mediterranean river, with strong flow variation during the year, and maximum discharges in Autumn and Spring. Maximum flows coincide with seasonal rainfall. Also typical of Mediterranean rivers is the long period of low flows and large interannual variability in water discharge (Giudicelli

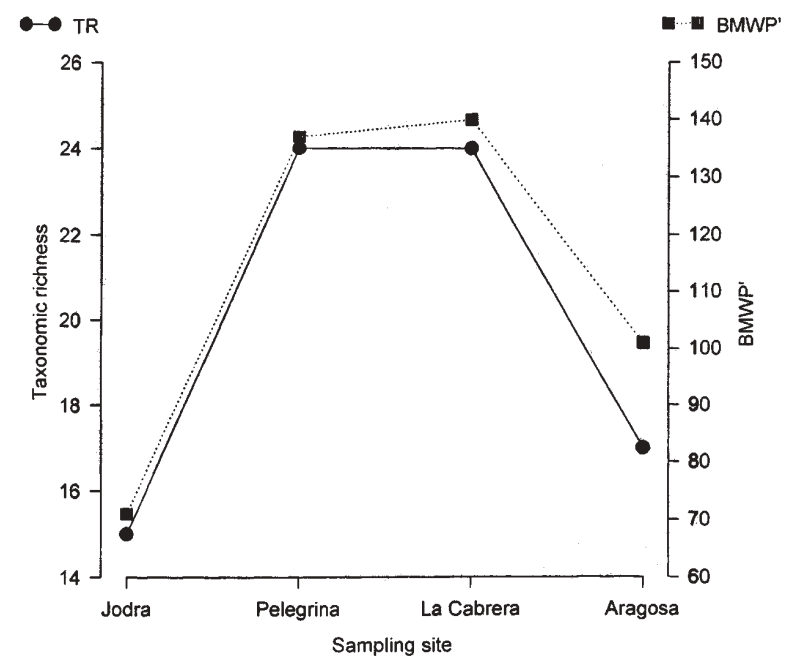

Figure 9. Spatial evolution of BMWP' index and taxonomic richness of fluvial macrobenthos in the River Dulce (Spain). Evolución espacial del indice $B M W P^{\prime} y$ de la riqueza taxonómica del macrobentos fluvial. et al. 1985; Mateu Bellés, 1989). During low water periods, water flow in River Dulce comes mostly from groundwater, with some sections of the river and most of tributary becoming dry (e.g. stream Saúca). This groundwater has a lower content of dissolved salts than the surface river except for carbonates and bicarbonates. In addition, groundwater has lower conductivity than water from surface run-off, which drains a basin with Keuper materials.

Hydrological functioning of River Dulce differs in four sections of the river, each with its own functional characteristics. The first section (I) maintains the pre-disturbed functions of the river. Here are the few zones still in pristine state. The river channel is not well-defined and a wide floodplain exists. Developed plant communities thrive here, adapted to a seasonally variable water regime, with high biomass and productivity (Sterling, 1996). The structure of this ecosystem (i.e. channel, floodplain, vegetation) helps maintain water quality and quantity by decreasing the destructive effects of floods and acting as a trap for sediments and nutrients (Maltby et al., 1996). Thse are incorporated into biomass by virtue of the high primary productivity of floodplains (Sterling, 1996). Preliminary results obtained support the hypothesis that ecosystem structure favours water depuration. Water with low quality entered the study area, and a sharp recovery occurred after passing through sector I. Thus, it could be nutrients are being incorporated into plant biomass and suspended solids are retained in the floodplain. Reduction in organic matter content would then allow an increase in oxygen levels and more diverse macrobenthos communities.

The importance of these systems must be stressed also in the light of their fragility. Where the original structure is altered (e.g. channel rectification, plant removal, ...), ecosystem functionality is lost. Examples of this can be seen in stream Saúca and some stretches of River Dulce near Jodra.

In sharp contrast, the river in sector IV flows at the bottom of a deep canyon. The water channel is well defined, and a permanent water flow 
exists. The channel has been altered to aid drainage of surrounding land. Aquatic vegetation is regularly harvested and the riparian forest replaced by Populus sp plantations. Although an active auto-depuration of water takes place in this part of the river, it is probably the result of higher water flow and turbulence rather than due to biological processes. $\mathrm{NH}_{4}^{+}$and $\mathrm{NO}_{2}{ }^{-}$ decreased, but $\mathrm{NO}_{3}{ }^{-}$increased because there was little incorporation of nutrients into plant biomass. This sector supports fish populations of interest to sport fishing, as well as endangered species such as otter (Lutra lutra) and Galemys pyrenaicus. Nesting colonies of vultures (Gyps fulvus) and other raptors are found nesting on the canyon walls (Arroyo, 1995).

The landscape of sector IV is preferred by both tourists and by the local population, as people can find water, trees, fish and birds in a peculiar setting. On the other hand, the landscape of sector I, upstream, is open and not favoured by potential users. This trend has been documented by authors who have demonstrated that in fluvial landscapes, preferred features are the presence of clean, transparent running water, abrupt landscapes (i.e. cliffs, canyons) and a vigorous and abundant vegetation, especially with trees (Martínez et al., 1989; Montes \& Martín de Agar, 1989).

A planning policy solely based on traditional criteria (i.e. protection of endangered species, maintenance of aesthetic landscape value, preferences of users; Junta de Comunidades de Castilla La Mancha, 1996) could leave upstream sectors of the River Dulce out of the protection limits. Upstream sectors today are under intensive exploitation. In the same way, some uses of the river are being promoted, such as the creation of permanent water habitats for the maintenance of fish populations, leading to the loss of the original ecosystems, which guaranteed water quality and flood control. From an ecological perspective, the upstream sectors are vital in the control of the whole fluvial ecosystem. They help improve water quality downstream. Their conservation and adequate management are urgently needed.

Mediterranean rivers, especially those of small size, have suffered large alterations in their structure as a consequence of the agricultural use of their flood plains. Modifications have been designed to facilitate their use as drainage channels (i.e. rectification of slope, channel deepening, elimination of aquatic vegetation and cutting of riparian forests; Ibero, 1966). Loss in the variety and complexity of ecological functions these systems supported has resulted (Mateu Bellés, 1989). For long these river ecosystems have been perceived as "unhealthy", and were supposed to be drained and then cultivated. On the other hand, temporary rivers are usually unfavourable environments for fish of commercial use or for sports fisheries. Perceptions and lack of sport fishing possibilities have led to the artificial desiccation of these habitats. Thus, landscapes conserving these original features are becoming increasingly rare.

It is clear knowledge on the ecological functions of river elements is needed during the planning of management of hydrological basins.

\section{ACKNOWLEDGEMENTS}

This paper has been produced during the management planning of the River Dulce basin. Work was funded by Junta de Comunidades de Castilla La Mancha and conducted by TRAGSATEC, S.A.

\section{REFERENCES}

ALBA-TERCEDOR, J. \& A. SÁNCHEZ-ORTEGA. 1988. Un método rápido y simple para evaluar la calidad biológica de las aguas corrientes basado en el de Hellawell (1978). Limnetica, 4: 51-56

AMAT, J.A., C. DIAZ PANIAGUA, C. M. HERRERA, P. JORDANO, J. R. OBESO \& R. C. SORIGUER. 1985. Criterios de valoración de zonas húmedas de importancia nacional y regional en función de las aves acuáticas. Monografías, 35. Instituto Nacional para la Conservación de las Naturaleza. Ministerio de Agricultura, Pesca y Alimentación. Madrid.

APHA, AWWA \& WPCF. 1989. Standard Methods for the Examination of Water and Wastewater. 17th. Ed. American Public Health Association, Washington D.C. 1592 pp. 
ARROYO, B. (Coord.). 1995. Censo de aves rupícolas de la provincia de Guadalajara. Consejería de Agricultura y Medio Ambiente. Junta de Comunidades de Castilla La Mancha.

CIRUJANO, S., M. VELAYOS, F. CASTILLA. \& M. GIL. 1992. Criterios botánicos para la valoración de las lagunas y humedales españoles (Península Ibérica y las Islas Baleares). Colección Técnica. ICONA. Madrid.

DAVIDSON, D. W., W. D. NEWMARK, J. W. SITES Jr., D. K. SHIOZAWA, E. A. RICKART, K. T. HARPER \& R. B. KEITER. 1996. Selecting wilderness areas to conserve Utah's biological diversity. The Great Basin Naturalist, 2(56): 95-117.

DE AZCÁRATE Y BANG, T. \& J. R. ABOAL VIÑAS, 1996. Las Categorías de Protección de los Espacios Naturales. Gobierno de Canarias.

ESTUDIOS BIOLÓGICOS, S.L. 1996. Inventario y Planes Técnicos de Gestión de los Cotos Trucheros de la Provincia de Guadalajara. Consejería de Agricultura y Medio Ambiente. Junta de Comunidades de Castilla La Mancha.

FERNÁNDEZ SAÑUDO, P., E. PÉREZ CORONA \& J. V. DE LUCIO. 1997. Criterios de definición de las categorías de protección de espacios naturales protegidos del Estado Español. Serie Documentos, $\mathrm{n}^{\mathrm{o}} 23$. Centro de Investigaciones Ambientales de la Comunidad de Madrid "Fernando González Bernáldez". Comunidad de Madrid.

GIUDUCELLI, J., M. DAKKI \& A. DIA. 1985. Caractéristiques abiotiques et hydrobiologiques des eaux courantes méditerranéennes. Verh. Internat. Verein. Limnol., 22: 2094-2101.

GONZÁLEZ BERNÁLDEZ, F. 1985. Invitación a la Ecología Humana. La Adaptación Afectiva al Entorno. Ed. Tecnos. Madrid.

GONZÁLEZ BERNÁLDEZ, F. 1988. Relación entre espacios naturales protegidos y protegibles. Los términos de una polémica. Coloquio Hispanofrancés sobre espacios naturales. Madrid.

IBERO, C. 1996. Ríos de Vida. Estado de conservación de las riberas fluviales en España. SEO/BirdLife.

JUNTA DE COMUNIDADES DE CASTILLA LA MANCHA. 1996. Análisis del medio físico para la localización de las Áreas Naturales de Conservación catalogadas en el Plan de Conservación del Medio Natural de Castilla La Mancha. Consejería de Agricultura y Medio Ambiente. Junta de Comunidades de Castilla La Mancha.
MALTBY, E., D. V. HOGAN \& R. J. MCINNES. 1996. Functional analysis of European wetland ecosystems. Phase 1 (FAEWE). The function of river marginal wetland ecosystems. DirectorateGeneral Science, Research and Development. EUR $16132 \mathrm{EN}$.

MARTÍNEZ, A., D. GALLARDO, F. G. BERNÁLDEZ \& J. P. RUIZ. 1989. La percepción del agua en el paisaje. Arbor, 518-519: 111-140.

MATEU BELLÉS, J. F. 1989. Ríos y ramblas mediterraneos. In: Avenidas fluviales e inundaciones en la cuenca del Mediterráneo. Gil Ocina, A. \& A. Morales Gil (eds.). Instituto Universitario de Geografía de la Universidad de Alicante. Caja de Ahorros del Mediterráneo.

MONTES, C. \& P. MARTÍN DE AGAR, 1989. Los humedales españoles como elementos del paisaje ibérico. Arbor, 518-519: 75-93.

MONTES, C. 1995. La gestión de los humedales españoles protegidos: conservación vs. confusión. El Campo, 132: 101-128.

MONTES, C., F. BORJA, M. A. BRAVO \& J. M. MOREIRA. 1997. Doñana: una Aproximación Ecosistémica. Consejería de Medio Ambiente. Junta de Andalucía.

MÚGICA, M., J. V. DE LUCIO \& F. D. PINEDA. 1996. The Madrid ecological network. In: Perspectives on Ecological Networks. Nowicki, P., G. Bennett. \& D. Middleton. (eds.). ECNC Publication Series on Man and Nature, vol 1.

PINEDA, F. D., F. DI CASTRI, C. G. ORCOYEN \& J. R. VILLANUEVA. 1991. Estudio y conservación de la diversidad biológica. In: Diversidad biológica/Biological diversity. Pineda, F.D., M. A.Casado, M. A. De Miguel \& J. Montalvo (eds.). Fundación Ramón Areces. Madrid.

SECCIÓN DEL ESTADO ESPAÑOL DE LA FEDERACIÓN EUROPEA DE PARQUES NATURALES Y NACIONALES DE EUROPA. 1994. Espacios Naturales Protegidos del Estado Español. Comunidad de Madrid.

STERLING CARMONA, A. 1996. Los sotos, refugio de vida silvestre. Ministerio de Agricultura, Pesca y Alimentación. Madrid.

UICN. 1994. Parques para la vida. Plan de Acción para las Areas Protegidas de Europa. ICONA. Madrid.

USHER, M. B. 1986. Wildlife conservation evaluation: attributes, criteria and values. In: Wildlife conservation evaluation. Usher, M.B. (ed.). Chapman and Hall. London. 